\title{
DID THE CONFINEMENT OF BOER CIVILIANS IN CONCENTRATION CAMPS BY THE BRITISH ARMY DURING THE ANGLO-BOER WAR (1899-1902) CONSTITUTE AN ACT OF GENOCIDE?
}

\begin{abstract}
This article addresses the confinement of Boer civilians in concentration camps by the British Army during the Anglo-Boer War (1899-1902), specifically whether this confinement and its ramifications might amount to an act of genocide. This possibility is often dismissed out of hand by historians, who usually claim that the tens of thousands of deaths in the camps can be attributed to incompetence and non-human factors. This article uses Vahakn Dadrian's definition of genocide, which considers indirect coercion as a tool of genocide. This type of coercion allows for concealing the actual ways adopted for achieving "population reduction". This article argues that though the tens of thousands of deaths that occurred in the camps were not the result of direct physical violence, they nevertheless satisfy Dadrian's definition of an act of genocide.
\end{abstract}

Key words: British Empire; concentration camps; genocide; Second Boer War; South Africa

\section{CZY ZAMKNIĘCIE CYWILNEJ LUDNOŚCI BURSKIEJ W OBOZACH KONCENTRACYJNYCH PRZEZ ARMIE BRYTYJSKA PODCZAS DRUGIEJ WOJNY BURSKIEJ (1899-1902) STANOWI AKT LUDOBÓJSTWA?}

Streszczenie

Artykuł podejmuje kwestię internowania cywilnej ludności burskiej w obozach koncentracyjnych przez armię brytyjską
HECTOR RIBEIRO University of St. Andrews, United Kingdom E-mail: hector.c.ribeiro@gmail.com http://orcid.org/0000-0002-2699-1485

CITATION: Ribeiro, H. (2020) Did the confinement of Boer civilians in concentration camps by the British Army during the Anglo-Boer War (1899-1902) constitute an act of genocide? Sprawy Narodowościowe: Seria nowa, 2020(52), Article 2274

https://doi.org/10.11649/sn.2274

This work was supported by the author's own resources. No competing interests have been declared.

This is an Open Access article distributed under the terms of the Creative Commons Attribution 3.0 PL License (creativecommons.org/licenses/by/3.0/pl/), which permits redistribution, commercial and non-commercial, provided that the article is properly cited. (C) The Author(s) 2020

Publisher: Institute of Slavic Studies, Polish Academy of Sciences

Publishing History: Received 2020-04-09; Accepted 2020-12-13; Published 2020-12-23 
podczas drugiej wojny burskiej (1899-1902), w szczególności w świetle pytania, czy ten rodzaj odosobnienia oraz jego konsekwencje należy uznać za akt ludobójstwa. Taka możliwość bywa od razu odrzucana przez historyków, którzy zwykli twierdzić, że dziesiątki tysięcy ofiar śmiertelnych w tych obozach to jest efekt niekompetencji i czynników pozostających poza kontrolą ludzi. Autor artykułu odwołuje się do definicji ludobójstwa sformułowanej przez Vahakn Dadriana, według której przymus pośredni zalicza się do arsenału narzędzi ludobójstwa. Ten rodzaj środka przymusu pozwala ukryć rzeczywiste sposoby, które mają spowodować "zredukowanie populacji”. Artykut dowodzi, że jakkolwiek śmierć kilkudziesięciu tysięcy osób w obozach nie była następstwem bezpośredniego użycia przemocy fizycznej, to jednak definicja ludobójstwa podana przez Dadriana zmajduje tu zastosowanie. [Przekł. Jacek Serwański]

Wyrazy kluczowe: Imperium Brytyjskie; obozy koncentracyjne; ludobójstwo; druga wojna burska; Afryka Południowa

\section{INTRODUCTION}

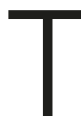

he Anglo-Boer War - also known as the Second Boer War, or the Tweede Vryheidsoorlog ("Second War of Liberation") in Afrikaans - was fought from October 1899 to May 1902 in Southern Africa, between the British Empire and two allied Boer republics: the Orange Free State and the South African Republic. In November 1900, Earl Horatio Kitchener took over from General Frederick Roberts as Commander-in-Chief of British forces in South Africa, a command he would hold until the end of the war. During his tenure, Kitchener drastically escalated the scorched earth strategy implemented by his predecessor, a strategy ostensibly designed to deprive Boer forces (which from an early stage in the war embraced guerrilla-style insurgency tactics) of the necessary resources to continue fighting (Forth, 2017, pp. 129-130, 144; Raath, 1999, pp. 1-2; Van Heyningen, 2013, pp. 58, 62-63). This strategy entailed the systematic destruction of large swathes of countryside, including farms, crops, livestock, and homes across the two Boer republics, with the Boer civilians residing in these areas being rounded up and forcibly sent to concentration camps in the British Cape Colony (Pakenham, 1979, p. 493; Surridge, 2012, pp. 614-615). Over the course of the war, over 25,000 people died in these camps (Van Heyningen, 2013, pp. 136-137), most of whom were children, the main causes of death being epidemic diseases such as measles, typhoid and dysentery (Smith, 2001, p. 5).

Most non-South African analyses of whether the use of concentration camps constituted an act of genocide dismiss the notion out of hand, arguing that the deaths were an unintended by-product of a military strategy with no genocidal intentions (Porter, 2000, pp. 638-641; Pretorius, 2010, pp. 34-39). ${ }^{2}$ In this analysis of the question, the term "genocide" will be used in accordance with its definition by sociologist and genocide scholar, Vahakn Dadrian: "the successful attempt by a dominant group, vested with formal authority and/or with preponderant access to the overall resources of power, to reduce by coercion or lethal violence the number of a minority group" (Dadrian, 1975, p. 201).

Dadrian's definition is particularly useful with regard to the Boer concentration camps because the deaths that occurred therein were not a result of direct physical violence but rather of coercion and calculated neglect, a fact often cited by those who refute the idea

1 I sincerely thank Tomasz Kamusella for his advice and support.

2 Also see - Farwell (1976), Ferguson (2002), Martin (1957). 
that the camp system was genocidal (Pretorius, 2010, pp. 34-39). This essay will argue however, that the confinement of Boer civilians in concentration camps by the British Army was a deliberate policy of reducing the numbers of a minority group through coercive means, and that therefore in accordance with Dadrian's adopted definition, it did indeed constitute an act of genocide.

\section{"THE ONLY WAY"?}

In evaluating whether the concentration camp system instituted by the British Army satisfies Dadrian's definition of genocide, it must be established whether the deaths that occurred in the camps constituted a "successful attempt" to reduce the Boer population (Dadrian, 1975, p. 201). As such, it is necessary to evaluate the claim that the deaths were merely an unintended consequence of Kitchener's military strategy. When first criticised for the high mortality rates within the camps, British Army officers claimed that the camps were a military necessity, of which the high mortality rate was an unintentional but unavoidable side effect - Kitchener himself declared "I wish I could get rid of these camps but it is the only way to settle the country" (Dadrian, 1975, p. 201). Both contemporaries and a number of historians writing about the subject subsequently (Ferguson, 2002; Pakenham, 1979; Spies, 1977) have made similar arguments, claiming that the deaths in the camps were simply regrettable casualties of war, no different from civilian casualties caused by collateral damage in any other conflict.

Kitchener himself justified the establishment of concentration camps by arguing that Boer women and children were legitimate military targets, claiming that it was "the women keeping up the war" (Arthur, 2007, p. 12) by providing supplies and intelligence to Boer commandos, and that therefore "all Boers without exception are targets" (Nasson, 2007, p. 95). Following this logic, the removal of Boer civilians from their lands and their concentration into camps therefore served to prevent them from aiding Boer commandos in their ongoing guerrilla campaign.

This line of argument is untenable however, when one considers that this military objective had already been achieved before the first of the "refugee camps" had even been constructed (Forth, 2017, pp. 150-151). During the initial British invasion of the two Boer republics, all major towns and cities were quickly captured and fortified by the British Army, with Boer civilians from nearby farms and villages subsequently concentrated inside them (Forth, 2017, pp. 150-151). Following the introduction of Kitchener's concentration camps policy however, those civilians already confined in fortified towns were transferred en masse to the newly constructed camps, as were all civilians subsequently rounded up during the British Army's various rural expeditions that continued until the end of the war (Forth, 2017, pp. 150-151).

Considering that the fortified towns already fulfilled the purpose of concentrating Boer civilians under British supervision, and prevented them from interacting with Boer commandos, it would seem clear that their deportation to purpose-built camps was not a military necessity. Indeed, Emily Hobhouse, who visited several concentration camps during her campaign to raise awareness about conditions therein, recounted how one camp she visited had "no soldiers or sentries, and most of the people [were] free to walk into town

3 Kitchener, H. (9 May 1901). Letter to St John Brodrick (Kitchener, 1901).
} 
or receive visits" (Raath, 1999, p. 43) a stark contrast to the rigidly controlled life of civilians within British-occupied towns. ${ }^{4}$ This would seem to heavily undermine the idea that the camps were a more effective security measure.

It is also important to note that the forced removal of civilians from their homes was totally indiscriminate, with no measures being taken to determine whether or not the civilians in question had aided Boer commandos - "there is no pretence that there was treachery, or ammunition concealed, or food given, or anything. It was just that an order was given to empty the country" (Raath, 1999, p. 50). It is worth keeping in mind that this policy, by definition, constituted an act of ethnic cleansing (United Nations Office on Genocide Prevention and the Responsibility to Protect, n.d.), as it involved the targeted and forced removal of all members of a particular ethnolinguistic group (the Boers), from a specific geographic area. Further discussion of the issue of the use of ethnic cleansing by the British Army during the Anglo-Boer War is beyond the scope of this essay, however it is interesting to note that most historical works on the subject, even those published after the term "ethnic cleansing" entered academic lexicon during the 1990's, do not address this subject. This is especially strange, since even those historians who deny that the confinement of Boer civilians in concentration camps constituted an act of genocide, do not refute the fact that Boers were removed en masse from their homes and sent to British-controlled areas purely on the basis of their ethnicity and language. ${ }^{5}$

It would seem clear therefore, that the concentration camp system was not instituted purely to deprive Boer commandos of supplies and intelligence, as this could have been accomplished without the costly and complicated process of constructing purpose-built camps. The camp system itself was therefore a deliberate attempt to achieve a different objective. The pursuit of this objective necessitated the transfer of civilians from fortified towns where living conditions were relatively good (Forth, 2017, pp. 150-151), to camps where these civilians were "barely supplied with the necessities of life" (Raath, 1999, p. 183) and where tens of thousands of them would die.

\section{INTENT OR INCOMPETENCE?}

The question of intentionality regarding the Boer civilian deaths that occurred in the concentration camps is central to determining whether they constituted an act of genocide. Historians arguing that the deaths in the camps were unintentional frequently cite the fact that the immediate causes of the deaths were non-human factors - principally disease - for which there is no evidence of the British Army deliberately encouraging, and the spread of which the Army eventually brought under control (Farwell, 1976, p. 392; Ferguson, 2002, p. 235; Martin, 1957, p. 7). However, when the concentration camp system is considered in the wider context of the British Army's policies during the Anglo-Boer War, as well as the British Empire's colonial policies during this period, it would seem clear that the deaths that occurred in the camps cannot simply be attributed to benign neglect.

The spread of the various diseases responsible for the high mortality rate in the camps, though not engineered by the British Army, was facilitated and strongly exacerbated by various factors that were directly under the Army's control. The concentration

4 For life inside fortified towns see - Forth (2017, pp. 150-151).

5 See - Farwell (1976), Ferguson (2002), Martin (1957). 
camps were characterised by grossly inadequate sanitary facilities, insufficient medical staff, contaminated water supplies, and shortages of bedding, food, and fuel; all of which were compounded by severe overcrowding, as the Army's rural expeditions continuously rounded up more and more civilians for internment (Pakenham, 1979, p. 505; Raath, 1999, pp. 143-145, 169-171; Surridge \& Judd, 2013, p. 195).

Most of these issues were structural, existing before the first Boer civilians even entered the camps (Forth, 2017, pp. 151-152), as such, the consequences of crowding hundreds of thousands of women and children into such camps would have been apparent from an early stage. Medical officials commenting on plans for the proposed camps described them as "quite insufficient accommodations for sick women and children," 6 warning from an early stage that "the introduction of disease into these camps... would be impossible... to escape." 7 upon learning of the proposed rations for civilians interned in the camps, one army doctor warned that "death from sheer starvation (uncomplicated by disease) would probably result within a few months. ${ }^{8}$ Considering that these medical professionals were employed by the army, the fact that they were prepared to voice their disapproval in such terms is compelling evidence of the extent to which the planning and organisation of the camps made a high death rate among internees almost inevitable.

Such warnings were ignored by the Army, meaning that the camp system was set in motion despite those responsible being aware of the serious health ramifications that such a system might have. It did not take medical qualifications however to understand the consequences of establishing mass internment camps that were so clearly lacking in basic life necessities. Army officers were well aware of "the difficulty of maintaining the health even of troops all in the prime of life". ${ }^{9}$ Indeed, the spread of disease was characteristic of late-19 ${ }^{\text {th }}$ century colonial warfare (Surridge, 2012, pp. 616-618) and during the Anglo-Boer War was responsible for a higher number of soldiers dying than enemy action (Nash, 1914, p. 309). It would seem highly improbable therefore, that an officer possessing Kitchener's level of military experience would have been unaware that concentrating malnourished women and children in poorly prepared and undersupplied camps would likely result in the rampant spread of disease and a high death rate amongst those interned.

\section{"A HUNDRED EXPLANATIONS MAY BE OFFERED AND A HUNDRED EXCUSES MADE, THEY DO NOT REALLY AMOUNT TO AN ADEQUATE DEFENCE ${ }^{\prime \prime 10}$}

Senior military officers such as Kitchener would also have been aware of the likelihood of a high mortality rate in the camps based on the precedent set by the use of similar camps by the British Army in India (Forth, 2017, pp. 127, 188-189). Though officers in South Africa excused the high mortality rate in the camps by claiming that "no one... had any experience" (Hime, n.d.) in camp administration, the British Army had in fact constructed hundreds of concentration camps in British India over the course of the $19^{\text {th }}$ century during periods of strife (Forth, 2015, pp. 654-655, 662-666). Like in South Africa, a combination of malnutrition and disease led to a high mortality rate in these camps, which

6 Westerfield, W. J. Dr Westerfield's protest against conditions at Kimberley RC (Westerfield, n.d.).

7 Turner, G. (19 February 1901). Minute on Sanitation by Dr Turner (Turner, 1901).

8 Haldane, J. S. Memorandum by Dr J. S. Haldane on the Rations in the Concentration Camps (Haldane, n.d.)

9 Hime, T. W. Report by Dr Hime, Medical Inspector of Refugee Camps in the ORC (Hime, n.d.).

10 Milner, A. (7 December 1901). Letter to Joseph Chamberlain (Milner, 1901). 
was eventually drastically reduced after the introduction of various measures designed to improve living conditions (Forth, 2017, pp. 1-2, 41-42). Thousands of British military officers and administrators who served in South Africa had also been stationed in British India earlier in their careers (Forth, 2017, pp. 127, 188-189). Many of these men had been involved in the construction and organisation of camps in India (Forth, 2015, p. 669) or would have been aware of the improvements instituted there which succeeded in reducing camp mortality rates. Dr Thomas Hime, the chief medical inspector of the camps, recorded that the spread of epidemic diseases, as well as various other medical issues encountered by camp administrators was "recently observed in famine camps in India" (Hime, n.d.). Indeed, after political pressure eventually forced the Army to improve camp conditions, camp administrators' first steps were to consult officers with experience in Indian camp administration on how to do so, something that would have been possible from before the first camp had even been constructed (Forth, 2017, pp. 127, 188-189). Even Millicent Fawcett, the head of the government-appointed commission dispatched to evaluate conditions in the camps, who was an open supporter of the camp system (Krebs, 1992, p. 46), concluded that "in every camp there has been an exceptionally bad outbreak of disease we think we see causes which more foresight and better organisation might have removed" (Forth, 2017, p. 192).

The squalid conditions within the camps were worsened by mismanagement on the part of camp administrators, who on several occasions knowingly transported sick internees to largely healthy camps, spreading disease from camp to camp in the process (Raath, 1999, p. 168). Meanwhile, thousands of healthy civilians who had recently been rounded up by Army expeditions into rural areas were sent to camps that were "already known to be unhealthy and full of fever" (Raath, 1999, p. 59). Warnings by medical officers were ignored and in some cases even covered up - Dr Hime, who consistently supported the camp system throughout his tenure, recorded that several camp doctors claimed that their reports had been censored or even destroyed by camp superintendents seeking to cover up the squalid conditions within camp hospitals (Raath, 1999, p. 216). The fact that the high mortality rate within the camps was predicted, exacerbated, and even covered up, would seem to constitute clear proof of intent on the part of the British Army to cause mass death among camp internees.

Perhaps the best indication that the neglect of Boer civilians interned in the camps was conscious and wilful, was the fact that once the British government put pressure on the Army to improve conditions in the camps, it did so swiftly and effectively. The effects of these improvements were drastic - by the end of summer 1901-1902, the annual mortality rate within the camps had fallen to $2 \%$, less than one twentieth of what it had been only 6 months earlier (Hobhouse, 1902, pp. 327-331). This demonstrates that the British Army was fully capable of addressing the terrible conditions in the camps from the beginning and consciously avoided doing so despite knowing the consequences of continued inaction.

The argument that British camp administrators should not be seen as responsible for the deaths that occurred in the camps was perhaps most clearly disproven by the statements of Alfred Milner, the Governor of the Cape Colony and administrator of the occupied Boer territories during the war. Milner admitted in a private letter that "a hundred explanations may be offered and a hundred excuses made, they do not really amount to an adequate defence... the enormous mortality was not merely incidental to the first formation of the camps" (Milner, 1901). The fact that the highest-ranking British official in 
South Africa privately acknowledged that the high mortality rate in the camps was avoidable and inexcusable, would seem to be damning evidence that the deaths that occurred cannot be attributed to non-human factors. It would seem that the high mortality rate within the concentration camps, though not a result of lethal violence, was not simply an inevitable side-effect of the use of concentration camps and cannot simply be attributed to British incompetence. Instead, the tens of thousands of deaths were a result of continuous, conscious, and intentional neglect that stemmed from the highest levels of the British Army.

\section{"BLOT OUT THE BOERS AS A NATION"11}

Far from unintentional, the wilful neglect that characterised the camp system was intended to inflict suffering on the Boer people, so as to force the Boer commandos to abandon their guerrilla campaign and surrender. General Roberts, one of the main architects of the camp system alongside Kitchener, declared that "Unless the people are generally made to suffer for the misdeeds of those in arms against us the war will never end" (Boje, 2015, p. 97). Exhibiting a similar mentality, Kitchener stated his intention to win the war by "aim[ing] at the Boers where they are most vulnerable... their farms must be burnt down, their wives and children separated from the men" (Nasson, 2007, p. 95).

This reflected the prevalent attitude within the British Army that conventional privileges given to civilians during wartime could not be extended to Boers, who were instead regarded as legitimate targets in the pursuit of military victory (Spies, 1977, pp. 296-297; Wessels, 2016, p. 164). This attitude was partially rooted in the idea that by having supported the commandos, Boer women had sacrificed their right to be treated as civilians (Forth, 2017, pp. 138-139), as argued by Millicent Fawcett - "no one can take part in war without sharing in its risks, and the formation of the concentration camps is part of the fortune of war" (Krebs, 1992, p. 46). Indeed, the extent to which the lines between combatants and civilians became blurred during the conflict was reflected in the rhetoric of British soldiers and civilian commentators alike, who referred to Boer women as "our principal enemies" (Van Heyningen, 2013, p. 51) and claimed that "women and children make war on us" (Wallace, 1901). The fact that Boer civilians were seen by the architects of the concentration camp system as enemies who should be made to suffer would certainly seem to undermine the idea that the appalling conditions within the camps and the high death rate amongst internees were unintentional.

Racial prejudice also played a significant role in rationalising the concentration camp system and does much to explain why the high death rates in the camps went unaddressed by the Army until political pressure was exerted upon it (Forth, 2015, pp. 668-669). The Anglo-Boer War occurred during a period when the works of figures such as Herbert Spencer and Francis Galton had gained widespread circulation, and their influence is readily apparent in the efforts on the part of the British Army to justify and rationalise the camp system (Krebs, 1992, pp. 44-45).

British officers and soldiers alike considered the Boers to be biologically and culturally inferior to Europeans, claiming that Boers could therefore not expect the same treatment as civilians in a European warzone (Forth, 2017, p. 138). John Buchan, Kitchener's pri-

11 Methuen (1901, p. 73). 
vate secretary, referred to the Boers as "half savage," claiming they had been collectively "orientalised" by living in Africa for generations (Buchan, 1903, pp. 48, 34-35). The British also regarded the semi-nomadic way of life of many Boers as evidence of their lack of civilisation (Krebs, 1992, pp. 44-45) drawing on Darwinist ideas of a civilizational hierarchy, in which settled societies were inherently superior to and more civilised than nomadic ones (Buchan, 1903, pp. 41, 48).

Governor Alfred Milner, for example, described the war in terms of a clash between modern civilisation, embodied by the British empire, and barbarism, embodied by the Boers (Wrench, 1958, pp. 13-17) whom he described as "a low type of the genus homo" (Krebs, 1999, p. 117). These racial attitudes, inflamed by frustration with the protracted Boer guerrilla campaign, at times evolved into genocidal rhetoric, with one jingoistic war correspondent calling on soldiers to "blot out the Boers as a nation," arguing that the Boer population should be "slain with the same ruthlessness... [as] a plague-infested rat" (Methuen, 1901, p. 73). Similar dehumanisation was exhibited by Kitchener himself who boasted of a "weekly bag" of captured and killed commandos in his personal diary (Kruger, 1960, p. 404). With direct reference to the concentration camp system meanwhile, Kitchener argued that "like wild animals... [Boers] have to be got into enclosures" (Forth, 2017, p. 143), providing insight into the mentality that lay behind the conscious and ultimately lethal neglect exhibited by the British Army towards Boer civilians interned in the camps. ${ }^{12}$

It would seem that while the identification of Boer civilians as military targets helped to rationalise the concentration camp system in the eyes of its architects, the dehumanisation of the Boer people as a whole served as the system's ideological underpinning. While it is true that the dehumanisation and mistreatment of enemy civilians have been common features of warfare throughout history - especially when facing an enemy waging guerrilla warfare - during the Anglo-Boer war they can be observed not in the form of spontaneous and isolated atrocities carried out at a squad-level, but rather in the systematic targeting of the civilian population as part of a strategy orchestrated at the highest levels of the British Army command structure. In Kitchener's eyes Boer civilians were both subhuman, and a valid military target, therefore their confinement in camps where it was widely predicted that many of them would die, was both rational and morally conscionable.

\section{"A SORT OF NATIVE RESERVE"13}

It is important to keep in mind that though Boer concentration camps received the larger share of attention from both contemporaries and subsequent historians, at least 115,000 black civilians living in the Orange Free State and South African Republic were also interned in separate concentration camps as part of Kitchener and Roberts' scorched earth strategy (Van Heyningen, 2013, p. 150). Those historians who have addressed the subject of the black concentration camps have proposed a range of estimates for the total number of people who died within them, though nearly all acknowledge that the real number likely far exceeds the official figure of 14,154 (Van Heyningen, 2013, p. 169; Wessels, 2016, p. 163).

12 For further insight into Kitchener's attitude towards Boers see - Magnus (1968, p. 177).

13 De Lobtinière, H. G. (18 January 1902) (De Lobtinière, 1902). 
The existence of black concentration camps, and the fact that death rates in these camps were proportionately even higher than in Boer camps, would seem to undermine the argument that the British concentration camp system was intended to accelerate military victory, as the suffering of interned black civilians would have had little impact on the resolve of Boer commandos. This begs the question of what the purpose of the black concentration camps was - a subject on which this article is admittedly not focussed. Having said this, this author proposes that the purposes of the respective camp systems were very much distinct.

Though both systems officially served the military goal of depriving Boer commandos of resources and civilian support, in practice, while Boer internees were treated as prisoners, black internees were used as a labour force by the British Army. The Native Refugee Department, responsible for managing black "refugees," was created specifically in order to make the black concentration camps more economically self-sufficient (Van Heyningen, 2013, pp. 162-163). To this end, internees were put to work in British-controlled farms and labour projects to provide food for themselves and to raise revenue to support the war effort (Van Heyningen, 2013, pp. 162-163). No equivalent institution was created for Boer civilian internees, who were never used as labourers in such a concerted manner by camp authorities. Unlike Boer camp internees, who were perceived as enemies by the British Army and whose suffering directly served the Army's military goals; black internees were perceived and treated as an expendable labour force - "the natives cannot reasonably be considered anything but hewers of wood and drawers of water"14.

Racial prejudice also played an important role in explaining the proportionately higher death rate in the black concentration camps. Perceived as even more inferior than "orientalised" Boers, blacks occupied the lowest position on the British Army's list of priorities for the provision of supplies and basic necessities (Van Heyningen, 2013, p. 154; Wessels, 2016, p. 164). Indeed, per capita the British Army spent more than three times as much on Boer camp internees than it did on black internees (Forth, 2017, p. 172), who were in turn given only half the food rations allocated to their Boer counterparts (Van Heyningen, 2013, p. 154). In addition to serving to help balance the books, these policies also reflected the institutional dehumanisation of black South Africans by members of the British Army and civilian administration, perhaps most clearly demonstrated by Major H. G. de Lobtinière, head of the Native Refugee Department who described black concentration camps as "a sort of native reserve" (De Lobtinière, 1902).

The high death rate in the black camps can therefore be attributed to a combination of racial prejudice, and the prioritisation of financial considerations above the preservation of human life. Though reprehensible, this treatment was informed by very different considerations to those which determined the death rate in the Boer camps, and therefore does not contradict the argument that the Boer concentration camp system was genocidal in nature.

\section{CONCLUSION}

Overall, it would seem clear that the deaths of tens of thousands of Boer civilians in British concentration camps during the Anglo-Boer War, were neither inevitable, nor unin-

14 Goold-Adams, H. A. (8 July 1902) (Goold-Adams, 1902). 
tentional. The official objective of the concentration camps had already been achieved before the first camp was even constructed, with fortified towns serving to concentrate the civilian population into small, easily controllable areas where they could not aid the Boer commandos. Nevertheless, the British Army went out of its way to construct camps (a costly endeavour at a time when it was under pressure to reduce expenditure; Forth, 2017, p. 162) where Boer civilians were forced to live in drastically worse conditions in which many of them died.

The spread of epidemic diseases, the main cause of death in the camps, was a predictable outcome which would have been obvious to senior officers with the level of experience possessed by Kitchener and Roberts. Regardless, various different Army officials issued warnings regarding the likely consequences of crowding large numbers of refugees into camps that lacked basic health and safety provisions. In spite of this, not only were these warnings ignored, but even after tens of thousands of internees died, no concerted effort was made by the Army to improve conditions until political pressure was exerted by the British government. When this conscious neglect is considered in the context of the dehumanisation of the Boer people by senior officers and the institutionally prevalent attitude that Boer civilians were legitimate military targets, it would seem clear that the high mortality rate in the camps cannot simply be attributed to incompetence or a lack of resources.

Kitchener's ultimate objective as Commander-In-Chief was to achieve military victory in the shortest possible timeframe. However, in the pursuit of victory he was, by his own admission, prepared to utilise a strategy which would by its very nature inflict death and suffering upon the civilian population - "you will not conquer these people until you have starved them out" (Boje, 2015, p. 49) - a conclusion which clearly formed the basis for his scorched earth strategy and the creation of the concentration camp system.

The concentration camp system served as an unsuccessful attempt to force Boer military forces to surrender by essentially holding their civilian population hostage, forcing the commandos to choose between surrendering, or allowing their relatives suffer and die by the thousand. This policy was perhaps no better exemplified by the fact that the relatives of Boer men who were known to be "on commando", were given smaller rations than other civilians, which were only increased to the normal level if those men surrendered to British forces (Haldane, n.d.).

Though there is no clear evidence that Kitchener sought to reduce the Boer population as a goal unto itself, this does not prevent the concentration camp system from being considered an act of genocide according to Vahakn Dadrian's definition. Kitchener, as the head of a dominant military force which enjoyed an overwhelming advantage in terms of resources of power, consciously implemented a military strategy the outcome of which he knew would result in the reduction of the Boer population through indirect but coercive means. Indeed, had public outcry and political pressure not forced the Army to improve conditions in the camps, it is probable that tens of thousands more civilians would have died before the war's end, as was the case in black concentration camps, which continued to experience very high mortality rates well into 1902 (Pakenham, 1979, pp. 493-495, 531-536). As such, it would seem clear that according to Dadrian's definition, the confinement of Boer civilians in concentration camps by the British Army during the Anglo-Boer War, did constitute an act of genocide. 


\section{Primary Sources:}

Buchan, J. (1903). The African colony, studies in the reconstruction. William Blackwood and Sons.

De Lobtinière, H. G. (1902, January 18). Commonwealth Office (CO 358/02), The National Archives, Kew.

Goold-Adams, H. A. (1902, July 8). Commonwealth Office (CO 82/2459/02), The National Archives, Kew.

Haldane, J. S. (n.d.). Memorandum by Dr J. S. Haldane on the Rations in the Concentration Camps. Commonwealth Office (CO 879/75/3, No. 79), The National Archives, Kew.

Hime, T. W. (n.d.). Report by Dr Hime, Medical Inspector of Refugee Camps in the ORC. Orange Free State Depot (VAB SRC Vol. 31 RC10324), National Archives of South Africa, Bloemfontein.

Hobhouse, E. (1902). The brunt of the war and where it fell. Methuen.

Kitchener, H. (1901, May 9). Letter to St John Brodrick. Public Record Office (PRO 57/171), The National Archives, Kew.

Methuen, A. M. S. (1901). Peace or war in South Africa. Methuen.

Milner, A. (1901, December 7). Letter to Joseph Chamberlain. Milner Papers (MSS Milner 171), British Library, London.

Raath, A. W. G. (Ed.). (1999). The British concentration camps of the Anglo-Boer War 1899-1902: Reports on the camps. War Museum.

Turner, G. (1901, February 19). Minute on sanitation by Dr Turner. Transvaal Depot (NASA TAB CS 4 374/01), National Archives of South Africa, Pretoria.

United Nations Office on Genocide Prevention and the Responsibility to Protect. (n.d.). Ethnic cleansing. https://www.un.org/en/genocideprevention/ethnic-cleansing.shtml

Wallace, E. (1901, August 13). Woman - the enemy. Daily Mail.

Westerfield, W. J. (n.d.). Dr Westerfield's protest against conditions at Kimberley RC. Orange Free State Depot (VAB SRC Vol. 7 RC1869), National Archives of South Africa, Bloemfontein.

\section{Secondary Sources:}

Arthur, G. (2007). Life of Lord Kitchener (Vol. 2). Cosimo.

Boje, J. (2015). An imperfect occupation: Enduring the South African War. University of Illinois Press. https://doi.org/10.5406/illinois/9780252039560.001.0001

Dadrian, V. (1975). A typology of genocide. International Review of Modern Sociology, 5(2), 201-212. www.jstor.org/stable/41421531

Farwell, B. (1976). The Great Anglo-Boer War. Harper \& Row.

Ferguson, N. (2002). Empire: The rise and demise of the British world order and the lessons for global power. Basic Books.

Forth, A. (2015). Britain's archipelago of camps: Labor and detention in a liberal empire, 1871-1903. Kritika: Explorations in Russian and Eurasian History, 16(3), 651-680. https://doi.org/10.1353/kri.2015.0042 
Forth, A. (2017). Barbed-wire imperialism: Britain's empire of camps, 1876-1903. University of California Press. https://doi.org/10.1525/california/9780520293960.001.0001

Krebs, P. M. (1999). Gender, race, and the writing of empire. Cambridge University Press.

Krebs, P. (1992). "The last of the gentlemen's wars": Women in the Boer War concentration camp controversy. History Workshop, 33(1), 38-56. https://doi.org/10.1093/ hwj/33.1.38

Kruger, R. (1960). Good-bye Dolly Gray: The story of the Boer War. Lippincott.

Magnus, P. (1968). Kitchener: Portrait of an imperialist. Penguin.

Martin, A. C. (1957). The concentration camps 1900-1902: Facts, figures and fables. Howard Timmins.

Nash, E. (1914). Nash's war manual. Eveleigh Nash.

Nasson, B. (2007). Civilians in the Anglo-Boer War. In J. Laband (Ed.), Daily lives of civilians in wartime Africa: From slavery days to Rwandan genocide (pp. 85-111). Greenwood Press.

Pakenham, T. (1979). The Boer War. Abacus.

Porter, A. (2000). The South African war and the historians. African Affairs, 99(397), 633648. https://doi.org/10.1093/afraf/99.397.633

Pretorius, F. (2010). The white concentration camps of the Anglo-Boer War: A debate without end. Historia, 55(2), 34-49. http://www.scielo.org.za/scielo.php?script=sci_arttext\&pid=S0018-229X2010000200007\&Ing=en\&tIng=en

Smith, I. R. (2001). The origins of the South African War, 1899-1902. Longman.

Spies, S. B. (1977). Methods of barbarism? Roberts and Kitchener and civilians in the Boer Republics, January 1900-May 1902. Human \& Rousseau.

Surridge, K. (2012). An example to be followed or a warning to be avoided? The British, Boers, and guerrilla warfare, 1900-1902. Small Wars \& Insurgencies, 23(4-5), 608626. https://doi.org/10.1080/09592318.2012.709768

Surridge, K., \& Judd, D. (2013). The Boer War: A history. Bloomsbury Academic.

Van Heyningen, E. (2013). The concentration camps of the Anglo-Boer War: A social history. Jacana Media.

Wessels, A. (2016). The Anglo-Boer War (1899-1902) and its traumatic consequences. In P. Gobodo-Madikizela (Ed.), Breaking intergenerational cycles of repetition: A global dialogue on historical trauma and memory (pp. 160-173). Verlag Barbara Budrich. https://doi.org/10.2307/j.ctvdf03jc.14

Wrench, J. E. (1958). Alfred Lord Milner: The man of no illusions, 1854-1925. Eyre \& Spottiswoode. 